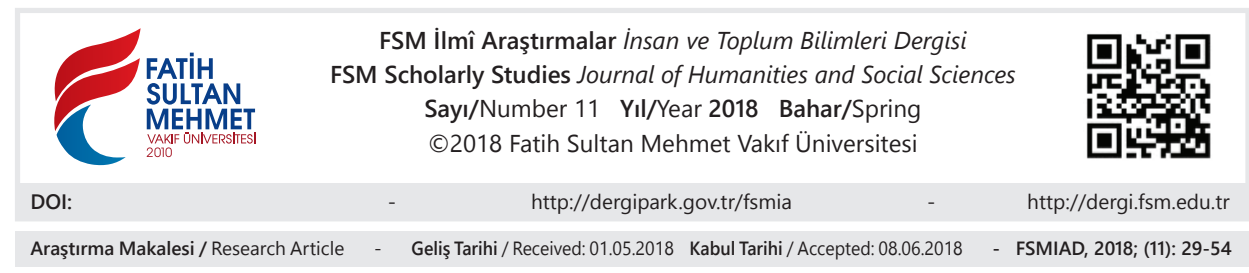

\title{
BM Güvenlik Konseyi Kararları Çerçevesinde Mali Krizi Naim Demirel*
}

\section{$\ddot{O} \mathbf{z}$}

Birleşmiş Milletler kuruluşundan bu yana özellikle 90'l1 y1llardan sonra aktif olarak uluslararasası barış ve güveniği koruma kapsamında etkin kararlar almaya başladı. Özellikle Yugoslavya kriziyle birlikte uluslararası toplumda uluslararası barış için bir umut doğdu. Artık soğuk savaş sona ermiş her iki bloğa ait devletler bir araya gelerek uluslararası barış için birlikte karar alabilir duruma gelmiştir. Hatta BM Güvenlik Konseyi uygulamalarında uluslararası ilişkilerde esaslı bir kural olan "iç işlerine karışma yasağı" (BM Sözleşmesi'nin 2/7. md) sebebiyle devletler arasında çatışma yokluğuna dayanan barışın "negatif barış" olarak anlaşılmasından yanında, bir devletin içinde de barış içinde birlikte yaşamayı ifade eden "pozitif barış" anlamıyla da uygulanması düşüncesi doğmaya başladı. Fakat bu umut uzun sürmedi. Rusya'nın kısa sürede kendini toparlamasıyla birlikte yine uluslararası toplumda çıkarlara dayalı kararlar alınmaya başlandı. Mali krizi bu alanda alınan son ortak kararlardan birisidir. Bu çalışmada Mali krizi çerçevesinde BM Güvenlik Konseyinin uluslararası barışın negatif anlamının yanında positif anlamı da kararında esas almış mıdır, sorusunun cevabı aranmaktadır.

Anahtar Kelimeler: BM Güvenlik Konseyi, uluslararası barış, uluslararası insancıl hukuk, kültür valıkları, Güvenlik Konseyi.

Doç. Dr., Fatih Sultan Mehmet Vakıf Üniversitesi Hukuk Fakültesi Uluslararası Hukuk Anabilim Dal1, İstanbul/Türkiye, ndemirel@fsm.edu.tr, orcid.org/0000-0002-3263-5348 


\title{
Mali Crisis Acccording to the Decisions of UN Security Council
}

\begin{abstract}
The United Nations (UN) has adopted effective resolutions since its foundation, particularly during 1990's, for the sake of promotion and protection of global peace and security. Especially following the UN's firm stance for the Yugoslavia crisis, the hopes for global peace have remarkably raised. The Cold Was had come to the end and the states from the opposite alliance blocks of the Cold War were enabled to make decisions altogether in order to protect global peace. In the UN Security Council's practice, even the idea that the concept of "positive peace," which regards the internal peace of states as a matter to be addressed by international community, could substitute the concept of "negative peace," which implies the peace situation only among states and does not regard internal peace of states because of the main principle of non-intervention enacted in Article $2 / 7$ of the UN Charter. Nevertheless, these hopes could not last long. As Russia could gather its strength after a short while, the decision-making mechanism of the international community became solely interest-based once again. In this article, the author is trying to examine the question whether the UN Security Council has endorsed the concept of "positive peace" or "negative peace" while its approach to Mali case, which is a remarkable international crisis occurred in 2000's.
\end{abstract}

Keywords: the United Nations Security Council, international peace, international humanitarian law, cultural property, Security Council. 


\section{Mali Krizini Hazırlayan Süreç}

Afrika'nın en geniş toprağa sahip devletlerinden birisi olan Mali Cumhuriyeti, 20.06.1960 tarihinde bağımsızlığına kavuşmuştur. Sekiz yönetim bölgesine ayrılmış olan ülke, çeşitli etnik gruplardan oluşmaktadır. Söz konusu gruplardan en kalabalığ 1 , ülkenin \%50'lik oranda nüfusuna sahip olan Mande ve Sarakole'dir. Bu grubu, nüfusun \%17'sini oluşturan Fula ve \%12'lik orana karşıllık gelen nüfusu Voltaic etnik grubu takip etmektedir. Ülke popülasyonunun \% 6'sın1 Songhay, \%4'ünü ise Araplar ve diğer etnik gruplar oluşturmaktadır. Mali'nin güneyinde siyahi halk yaşamakta iken Kuzey Mali'de göçer Tuareg, Songhay ve Araplar yaşamaktadır. Tuaregler ise ülke nüfusunun \%10'unu teşkil etmektedir.

Mali Cumhuriyeti bağımsızlığına kavuşana kadar Fransız sömürgesiydi. Bu dönemde Fransızlar, ağırlıklı olarak ülkenin güney bölgesine ekonomik yatırımlar yapmıştır. Bunun sonucu olarak da göçerlerin bulunduğu Kuzey Mali bölgesi ekonomik olarak geri kalmıştır. Bu bölgedeki yüksek işsizlik oranı ve önemli altyapı eksikliği öteden beri varlığını sürdürmektedir. Güney ve Kuzey arasındaki bu ekonomik dengesizlik ülkede bazı iç sosyal krizlere sebep olmaktadır.

Tuaregler; farklı gelenekleri, savaşçı yapıları ve güçlü aile bağlarıyla yukarıda sayılan etnik gruplardan ayrılmaktadır. Sahel bölgesinde yaşayan ve bu bölgeyi kontrolü altında bulunduran Tuaregler, yarı göçebe bir topluluktur. Berberî olarak bilinen Tuaregler; Cezayir, Libya, Burkina Faso ve Nijer'de de yaşamaktadırlar. Mali'de ise yaklaşı 300.000 Tuareg yaşamaktadır. Tuareglerin toplam nüfusu (Mali, Nijer, Cezayir, Libya ve Burkina Faso ülkelerinde yaşayan bütün popülasyon hesaba katıldığında) 1 ile 1,5 milyon olarak tahmin edilmektedir. Fransız sömürge yönetimine en fazla direnç gösteren topluluk Tuareglerdir. Geleneklerine bağlı olan Tuaregler, her zaman otonom yapılarını korumuşlar ve birçok defa merkezi hükümetlere karşı ayaklanmışlardır. Bu isyanların ana sebebi Mali'nin bağımsızlığa kavuşmasından sonra Kuzey'de yaşayan halka ayrımcılık uygulanmas1, Tuareglerin taleplerinin yerine getirilmemesi ile kültürel ve ekonomik haklarının ellerinden alınması hususunda duydukları korkudur. Tuaregler merkezi idare tarafından birçok defa yerleşik hayata zorlanmış ve bu zorlamaların sonucunda krizler ve çatışmalar ortaya çıkmıştır.

Tuareglerin ilk ayaklanmasi 1962 yılında olmuştur. Bu isyana katılanların sayısı azdı ve halktan fazla destek görmemişti, dahası bazı Tuareg grupları çatışmalar sırasında hükümetin yanında yer almıştı. Bu ayaklanma, merkezi hükümet tarafindan güç kullanılarak 2 yıl içinde bastırılmıştır. Bu durum sonucunda ülkenin kuzey bölgesinde askeri bir yönetim kurulmuştur. Ancak, hükümetin isyanın sebebini ortadan kaldırmaya yönelik politika uygulamak yerine güç politikası uy- 
gulamayı seçmiş olması mezkur sorunu çözüme kavuşturmamış aksine problemi daha da büyütmüştür.

Merkezi yönetimin Kuzeydeki halka uyguladığı askeri ve baskıcı yöntemlerin yarattığ problemlere 1970 ve 1980 yıllarında yaşanan çetin kuraklık sebebiyle bir de ekonomik kriz eklenmiştir. Bu nedenle, Tuaregler hayatlarını sürdürmek için yeni arayışlara yönelmiş ve komşu ülkelere göç etmeye başlamışlardır. Bu durum, Tuareglerin göç ettiği bölgelerde birçok tecrübe kazanmasına sebep oldu. Özellikle genç Tuaregliler, paralı asker olarak Kaddafi'nin ordusuna katıldılar. Sonuç olarak, 1980 yılı sonun itibarıyla yüzlerce Tuareg genci Libya'da askeri kamplarında eğitim görmüş oldu.

Tuaregler; 1980'li yılların sonlarına doğru Mali'de ikinci büyük ayaklanmanın hazırlığını yaptılar. Haziran 1990'da ise Iyad Ag Gali liderliğinde ayaklanan Azawad Kurtuluş Halk Hareketi (Popular Movement for the Liberation of Azaw/ PMLA), ikinci isyan hareketini başlattı. İsyancıların hedefi Tuareg Azawad Devletini kurmakt1. PMLA örgütü başlangıçta, askeri garnizonlara ve diğer devlet tesislerine ve sembollerine saldırmasının ardından Mali ordusuna karşı zafer kazandı.

Hükümet bu isyanı da yine sivil halka baskı ve şiddet uygulayarak bastırdı. Ancak hükümetin bu politikası ağır bir şekilde eleştirildi. Cezayir hükümetinin arabulucuğu ile isyancılar ile hükümet arasında Tamanrasset Antlaşması yapıldı. Fakat bu antlaşma başkent Bamako'da tepkiyle karşılandı. Büyük çaplı protestolardan sonra 26 Mart 1991 de bir askeri darbe sonucunda General Amadou Toumani Toure başkanlığındaki “Uzlaşı Konseyi” yönetime el koydu. Böylece ülkede süregelen 23 yıllık sosyalist yönetim sona erdi. 1992 de ise yeni anayasa kabul edilerek seçime gidildi. Seçimin ardından Kanore devlet başkanı oldu ${ }^{1}$. 1992 yılında isyancılarla Pact National'da ikinci barış antlaşması imzalandı. Bu antlaşma ile isyan resmi olarak sona erdirildi.

Kanore, ülkeyi bölünmeden kurtarmak ve Tuareg tehdidini tamamen ortadan kaldırmak amacıyla ülkenin kuzeyinde özerk bir yapı oluşturmak için çalışmalar yaptı. Yapılan antlaşma, Tuareg isyancılarının Mali ordusuna entegrasyonunu ve bu kişilerin bazı resmi görevlerde istihdamını öngörüyordu. Antlaşmanın yerine getirilmesi amacıyla yasal düzenlemeler yapılmış olmasına rağmen, hükümet tarafından verilen sözler yerine getirilmedi. Bunun sonucu olarak da taraflar arasında çatışmalar ve husumet bitmedi.

1996'da üçüncü barış antlaşması olan Flamme de la Paix andlaşması imzalandı. Bu Antlaşma ile birlikte 6 yıl süren isyan sona erdi. Ancak 2006 yılında

1 http://www.lag-malihilfe.de/mali-geschichte.htm. 
Mali ordusundan kaçan bazı Tuareglerin karakollara saldırmalarının akabinde iç karışıklıklar yeniden başladı. Hükümet sorunu barışçı yollar ile çözmek için çalışmalara başladı. Hatta bu çaba belli bir noktaya kadar da başarılı oldu. Ancak bazı grupların anlaşmaya uymamaları sebebiyle çatışmalar 2009'a kadar sürdü. Bu çatışmaların, 2012 tarihinde başlayacak olan büyük çaplı isyanın zeminini hazırladığı bilinmektedir.

2012 isyanının önderliğini Libya da yetişmiş Ag Bahanga, Iyad Ag Ghaly, Mahmoud Ag Aghaly gibi tecrübeli savaşçılar yürütmekteydi. Daha sonra Ulusal Azawad Kurtuluş Hareketi (National Movement for the Liberation of Azawad/ MNLA) kuruldu. İsyancılar 2012 yılının Şubat ayında, Kaddafi'nin yanında yer almak suretiyle Libya iç savaşında çatışmalara katılan savaşçıların da desteğini alarak Kuzey Mali'deki şehirlere ve kasabalara saldırdılar. Çatışma bölgelerinde yaşayan ve çoğunlukla Tuareglerden oluşan sayısı binler ile ifade edilebilecek sivil halk yerlerinden kaçarak komşu ülkelere sığındılar. ${ }^{2}$

Mali ordusu çatışmalarda çok sayıda asker kaybı verdi. Amadou Sanogo ${ }^{3}$ önderliğindeki askerler; Toure hükümetinin isyanı bastırma hususundaki başarısızlığına dayanarak, 21.03.2012'de Mali'de seçimle işbaşına gelen hükümete karşı darbe yaptı. İktidarı ele geçiren Amado Sanogo, MNLA ile ECOWAS himayesinde Burkina Faso'da görüşmeler yapacağını bildirdi. BM, Afrika Birliği ve Batı Afrika Ekonomi Topluluğu (ECOWAS) Başkan Toures'in görev süresinin dolmasına birkaç hafta kala yapılan darbeyi kınadılar ve hemen yeni bir seçim yapılması çağrısında bulundular. Ancak ülkenin içinde bulunduğu kriz yeni bir seçim yapılmasına müsait değildi. Bu nedenle, 12 Nisan 2012 tarihinde 2007'den beri Meclis Başkanlığı yapan Diacounda Traore ülkenin anayasanına göre geçici başkan oldu.

$\mathrm{Bu}$ arada MNLA, cephede başarılar elde edip; Kidal, Gao ve Timbultu gibi bazı yerleşim yerlerini kontrolünü altına aldı. Ardından, Azawad Devleti'ni kurduğunu 06.04.2012 tarihinde ilan etti.

Başlangıçta MNLA, Tuareg-Grup Ensar Dine tarafından desteklendi. Ancak daha sonra bu grup AQMI ( El-Kaide mağrip grubuyla) hızlı bir şekilde birlik kurdu. AQMI ve diğer radikal islami gruplar, seküler MNLA'dan askeri olarak daha güçlüydüler. Ancak MNLA'nın birçok militanının Ensar Dine safına geçmesi MNLA'yı zayıflattı. MNLA çatışmalar sonunda Kuzey Mali'deki kontrolünü Ensar Dine, AQMI ve MUJAO gruplara terk etmek zorunda kaldı. Diğer mücahit gruplar, Haziran 2012 den itibaren Kuzey Mali'yi kontrol eder duruma geldiler.

2 http://www.muz-online.de/afrika/mali.html.

3 2004'ten 2010'a kadar ABD'de askeri eğitim almıştır. 
Bu gruplar, hâkim olduğu şehirlerden kaçan binlerce sivil Güney Mali’ye ya da komşu devletlere sığındı. Çatışmalar sebebiyle yaklaşık 200.000 kişi yerlerinden göç ederek komşu ülkelere sığındı. Bölgede sivil halk gündelik ihtiyaçlarını temin edemez duruma geldi. Diğer taraftan da başkent Bamako'da yaşayan 60.000 Tuareg ve Arap, siyahi etnik grupların baskısına dayanamayarak şehirden çıkmak zorunda kaldılar. Bütün bu gelişmeler sonunda Mali, artık etnik gruplar arasında çatışmaların olduğu bir ülke haline geldi.

19.10.2012 tarihinde ECOWAS üyeleri, bölge devletleri ve ilgili bazı başka devletler Mali'deki krizin nasıl ortadan kaldırılacağına dair Bamaso'da bir araya geldi. Söz konusu devletler bu görüşmede bir karar tasarısı hazırladı. Bu karar tasarısı 24.10.2012 tarihinde Afrika Birliği Barış ve Güvenlik Konseyi tarafından kabul edildi ${ }^{4}$ 11.11.2012 tarihinde Abuja da özel gündemle toplanan ECOWAS Devlet ve Hükümet Başkanları Komitesi ile Afrika Birliği Barış ve Güvenlik Konseyi'nin 13.11.2012 tarihli sonuç bildirgesinde; uluslararası askeri birlik ve Mali Savunma ve Güvenlik güçleri için oluşturulan ortak stratejik müdahale planı kabul edildi ${ }^{5}$.

12 Ekim 2012 tarihinde BM Güvenlik Konseyi, Mali’ye müdahale etme kararının ardından ECOWAS ve Afrika Birliği Fransa'nın öncülüğünde müdahale hazırlığına başladı. Fransa'nın ısrarlı davranışı sonucunda BM Güvenlik Konseyi 20.12.2012 tarihinde toplandı ve S/RES/2085 (2012) sayılı kararı aldı. Başlangıçta Fransa, Mali’ye müdahale konusunda çekimser kalmıştı. Ancak İslamcı güçlerin beklenenin aksine sadece kuzeyde kalmayıp güneye doğru da genişlemeye başlayarak başkent Bamako'yu ele geçirecek hale gelmeleri üzerine geçici başkan Traore, Fransa'yı yardıma çağırdı. Bu gelişmeler sonucunda, MNLA ve Bamako yönetimi Ocak 2013 tarihinde İslami gruplara karşı birlikte hareket etme kararı aldı. 11.01.2013 tarihinde ise Fransız askeri birlikleri "SERVAL" adı altında askeri operasyonlara başladı. Bu operasyonlarda Fransa'ya ABD, $\mathrm{AB}$ ve $\mathrm{BM}$ destek verdi.

Fransa, cephede ECOWAS ve Mali askerlerinin de yardımıyla kısa sürede üstünlük sağlayarak MNLA ve İslami grupların ellerinde olan yerleri ele geçirerek Kidal'a doğru ilerledi. Fransa'nın MNLA'yı Tuareglerin meşru temsilcisi olarak kabul etmesi, İslamcı örgütlere karşı bu örgütü tercih etmesi ve onunla işbirliği yapması sayesinde cephede ilerleme kaydedildi.

Uluslararası müdahale ardından 28 Ocak'ta Kidal MNLA tarafindan kontrol altına alındı. Daha sonra MNLA Tessalit ve Khalil kasabalarını da ele geçirdi. 
30 Ocak’ta Fransız birlikleri Kidal havaalanına ulaştılar. Bunun üzerine muhalif diğer gruplar dağlara kaçtı. Bu askeri zaferle birlikte Kuzey Mali’de bu grupların hâkimiyetine son erdi.

28.07.2013 ve 11.08.2013 tarihlerinde başkanlık seçimi ve 24.11 .2013 ve 15.12.2103 tarihlerinde parlamento seçimi yap $1{ }^{1} 1^{6}$. 18 Haziran 2013 'te ise Ouagadougou' da hükümet ile MNLA arasında bir ön barış anlaşması yapıldd ${ }^{7}$. Başkan tarafından 23.04.2014 tarihinde Mali içindeki diyaloğu sağlamak için yüksek bir memur atand1 ${ }^{8}$. 17/18.05.2014 tarihlerinde Kidal'da, 21.05.2014'de de özellikle Kuzey Mali bölgesindeki şehirlerde çatışmalar çıktı. Bu çatışmalarda hükümete bağlı birlikler ve siviller öldü. MNLA bazı şehirleri ele geçirerek paralel idari yapilar kurdu. ${ }^{9}$

23.05.2014 tarihinde ateşkes anlaşması imzaland1. 30.07.2014 tarihinde Accra'da ECOWAS zirve toplantısı tertiplendi. 13.07.2014 tarihinde de ateşkesin icra edilme modelleri antlaşması imzaland $1^{10}$.

2012'de yapılan askeri darbeden sonra normal anayasal düzene geçişi öngören yol haritasındaki önemli kilometre taşlarından birisi, Kuzey Mali bölgesindeki silahlı gruplarla Haziran 2014'ten Mayıs 2015'e kadar süren ve Cezayir'de yapılan barış görüşmeleriydi. 15.05.2015'te Bamako'da hükümet ile bazı silahlı gruplar arasında barış anlaşması imzalandı. Bağımsızlık için mücadele eden bazı silahlı gruplar barış antlaşmasını imzalamamışlar ancak bu gruplarla görüşmeler sürmektedir.

Her ne kadar bir İslam devleti kurmak isteyen silahlı grupların gücü Fransız birliklerinin SERVAL operasyonu ile zayıfladiysa ise de söz konusu grupların Kuzey Mali'deki tehdidi hâlâ sürmektedir. Gerek BM barış gücü MINUSMA ve gerekse SERVAL'dan sonraki misyon BARKHANE arada silahlı saldırılara hedef olmaktadirlar. ${ }^{11}$

Kriz sebebiyle göç eden 200.000'in üstünde sivil halk 2013 yılının ortalarında kendi evleri olan Kuzey Mali’ye geri döndüler. Ancak sivil halktan 270.000 kişi hala geri dönmüş değildir. Bunlardan 140.000 'i komşu ülkelerde 90.000 'i ise başka şehirlerde bulunmaktadır. Geri dönüşün önünde engel teşkil eden husus ise ülkenin kuzeyinde devam eden güvenlik sorunudur.

\footnotetext{
6 S/RES/2164 (2014), prae.para.5.

7 S/RES/2164 (2014), prae.para.6.

8 S/RES/2164 (2014), prae.para.8.

9 S/RES/2164 (2014), prae.para.9.

10 S/RES/2164 (2014), prae.para.10.

11 https://www.afrikanistik-aegyptologie-online.de/archiv/2015/4127.
} 


\section{Mali Krizine Yönelik Güvenlik Konseyi Kararları}

\section{Güvenlik Konseyi’nin S/RES/2056 (2012) Sayılı Kararı}

Güvenlik Konseyi 05.07.2012 tarihinde toplandı. Bu toplantıda, Mali'de demokratik yollarla seçilmiş hükümetin, 22.03.2012 tarihinde Mali Silahlı Kuvvetlerinin bazı üyeleri tarafından darbeyle iktidardan uzaklaştırılmasını kınamış ve Mali Silahlı Kuvvetlerinin sivil otoriteye bağlılığının önemini vurgulanmış, Mali'de anayasal düzenin yeniden tesis edilmesi yolundaki Batı Afrika Ülkeleri Ekonomik Topluluğu (ECOWAS), Afrika Birliği (AU) ve diğer bölge ülkelerinin çalışmaları konusundaki takdirleri de ifade edilmiştir ${ }^{12}$.

Konsey bu kararında MNLA'nın yaptığı bağımsızlık ilanını tanımadığını, bu ilanın geçersiz olduğunu ifade etmiş, ${ }^{13}$ Mali'deki geçiş hükümeti ile farklı siyasi aktörlerin ve sivil toplum örgütlerinin arasındaki diyaloğun sürdürülmesinin ülkede yeniden düzenin sağlanması için önemli olduğunu dile getirmiştir. ${ }^{14}$

Konsey, ayrıca Sahel bölgesindeki silahlı gruplar ve terör örgütlerinin varlığ 1 ve faaliyetlerinin, aynı şekilde Sahel bölgesindeki ve bölgenin dışındaki silahlanmanın artmasının bölgedeki devletlerin istikrarını, barış ve güvenliğini tehdit ettiğini tespit etmiştir. ${ }^{15}$

Bu kararda, bölgede ve Kuzey Mali'de AQIM örgütünün varlığı ve terörist grupların tehditlerinin artması sebebiyle derin endişeler dile getirilerek, terörizmin her formu ve şekliyle barış ve güvenliği sarsan ciddi bir tehdit oluşturduğu vurgulanmış, hangi motifle olursa olsun, ne zaman, kime karşı işlenmiş olursa

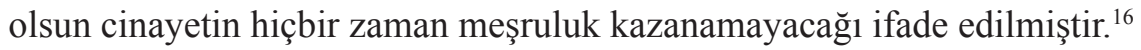

Kararda ayrıca, Mali'de terör grupları tarafından kazanç ya da politik kazanımlar elde etmek amacıyla adam kaçırma ve esir alma fillerinin artması, ülkedeki insani durumun kötüleşmesi, yurtlarından çıkartılanlar hakkında ve mültecilerin sayısındaki artış konusunda endişeler dile getirilerek, bütün taraflardan yardımların her hangi bir engelle karşılaşmadan ayrım gözetmeksizin bütün ihtiyaç sahiplerine ulaştırılması için faaliyet göstermeleri talep edilmiştir. ${ }^{17}$

\footnotetext{
12 S/RES/2056 (2012), pra.para 3.

13 S/RES/2056 (2012), pra.para 8.

14 S/RES/2056 (2012), pra.para 6.

$15 \mathrm{~S} / \mathrm{RES} / 2056$ (2012), pra.para 7.

16 S/RES/2056 (2012), pra.para 11

17 S/RES/2056 (2012), pra.para 12.
} 
Bölgede terör örgütleri tarafından tarihî eserlerin, kültürel ve kutsal yerlerin tahrip edilmesi ve bu eserlere zarar verilmesi fillerini, Konsey sert bir şekilde kınadi. $^{18}$

Konsey, bölgedeki bütün bu sayllan durumlara dayanarak Mali'deki durumun uluslararası barış ve güvenliği tehdit eden bir durum oluşturduğunu tespit etmiştir. ${ }^{19}$

Konsey, BM Sözleşmesi VII. bölüm çerçevesinde hareket ettiğini ifade ederek, ${ }^{20}$ Anayasal düzenin yeniden tesis edilmesi için Mali'deki bütün aktörlerden geçici hükümeti destekleyerek, kamu düzenin tesisi ve yeniden anayasal düzene geçişin temin edilmesi için gerekli şartları hazırlamalarını istedi. ${ }^{21}$ Kararda ayrıca ülkede Kuzey Mali'nin meşru temsilcileri de içinde olmak üzere sivil toplum ile politik güçler arasında milli bir mutabakat sağlanması ve Anayasal Düzenin yeniden tesisi için anlaşma yapıldıktan sonra 12 ay içinde serbest seçimlere gidilmesi talep edildi ${ }^{22}$.

Kararda, Mali silahlı kuvvetlerinin bütün birliklerinden sivil anayasa düzenine ve insan haklarına uyması istenmiş ${ }^{23}$ ve sivillere yönelik bütün saldırılar, cinsel şiddet, çocukların zorla askere alınmaları, çocuk savaşçıların çatışmalarda kullanılması ve sivillerin zorunlu iskânı fiilleri şiddetle kınanmıştır. ${ }^{24}$

Kararda Mali’nin ülkesel bütünlüğüne vurgu yapılarak, Kuzeydeki isyanc1 gruplardan düşmanca eylemleri derhal bırakmaları talep edilmiş ve MNLA, Ensar Dine gibi farklı örgütler bünyesinde faaliyet gösteren bütün yabanc1 savaşçılar, barış ve güvenliği tehdit eden ve hukuk devletiyle bağdaşmayan tüm faaliyetlerden uzak durmaları konusunda uyarılmıştır. ${ }^{25}$

Konsey, bütün taraflardan, yardıma muhtaç kişilere insani yardım malzemelerinin ulaştırılması konusunda söz konusu malzemelerin engellenmeden zamanında ulaşmasının ve insani yardım personelinin güvenliğinin sağlanması için uluslararası ve uluslararası insanc1l hukuk çerçevesinde gerekli bütün önlemleri almalarını istemiştir. ${ }^{26}$

18 S/RES/2056 (2012), pra.para 13.

19 S/RES/2056 (2012), pra.para 15.

20 S/RES/2056 (2012), pra.para 16.

21 S/RES/2056 (2012), op.para 2.

22 S/RES/2056 (2012), op.para 8.

23 S/RES/2056 (2012), op.para 4.

24 S/RES/2056 (2012), op.para 13.

25 S/RES/2056 (2012), op.para 10.

26 S/RES/2056 (2012), op.para 14. 
Konsey dini, tarihi anıtlara yapılan saldırıların, Cenevre Sözleşmesi II Nolu ek protokolü ve Mali'nin taraf olduğu Uluslararası Ceza Mahkemesi Roma Statüsü çerçevesinde değerlendirileceğini belirtmiştir. Ayrıca bütün tarafları dünya kültür mirasının korunmasını sağlamak konusunda uygun önlemleri almaya davet etmiştir. ${ }^{27}$

Konsey, bütün isyancı gruplardan, AQIM ve bağlı grupların ülke üzerindeki etkisinin azaltılması ve ülke bütünlüğünün korunması konusunda ${ }^{28}$ ve terörizmle mücadele kapsamında AQIM ile herhangi bir bağlantı kurmaktan uzak durmaya ve El-Kaide ile mücadeleye gerekli desteği vermelerini istemiştir. ${ }^{29}$

Konsey, terörizmle mücadele için daha önce aldığ 1267 (1999) ve 1989 (2011) sayılı kararlarını hatırlatarak, bu kararlar bağlamında gerekli çalışmaları yapmalarını Sahel bölgesindeki ve özellikle Kuzey Mali'ye komşu üye devletlerden talep etmiştir.

\section{Güvenlik Konseyi’nin S/RES/ 2071 (2012) Sayılı Kararı}

06.04.2012 tarihinde ECOWAS organizesinde Mali'de Anayasal düzenin yeniden tesis edilmesi, ulusal uzlaşının sağlanması, özgür, açık ve adil başkanlık seçimlerinin yapılmasına yönelik bir çerçeve anlaşması imzaland $1^{30}$.

01.09.2012 tarihinde Mali geçiş dönemi hükümeti, ECOWAS‘a bir mektup yazarak Mali güvenlik birliklerinin yeniden organize edilmesi ve terör gruplarınca kontrol altına alınan Kuzey Mali’de yeniden merkezi hükümetin kontrolünün sağlanarak ülkesel bütünlüğün yeniden tesis edilmesi için yardım talep etti ${ }^{31}$. Daha sonra 18.09.2012 tarihinde hükümet ve 28.09.2012 tarihinde ise ECOWAS, BM Genel sekreterine yazdığı mektupta BM Güvenlik Konseyi’nin, BM Sözleşmesinin VII. bölümü kapsamında alınan müdahale kararı ile bir uluslararası askeri güç oluşturarak Kuzey Mali'deki işgalin sona erdirilmesini talep ettiler. ${ }^{32}$

Bundan sonra 12.10.2012 tarihinde Güvenlik Konseyi toplanarak S/RES/ 2071 (2012) sayılı kararı aldı.

Konsey bu kararında, silahlı isyancıların, terörist grupların ve kuzey Mali'deki diğer aşırı grupların yaptıkları insan hakları ihlallerini, sivil halka karşı özellikle kadın ve çocuklara karşı kuvvet kullanılmasını, öldürme fiillerini, rehin

\footnotetext{
27 S/RES/2056 (2012), op.para 16.

28 S/RES/2056 (2012), op.para 22.

29 S/RES/2056 (2012), op.para 20.

$30 \mathrm{~S} / \mathrm{RES} / 2071$ (2012), pra.para.16.

31 S/RES/2071 (2012), pra.para.8.

32 S/RES/2071 (2012), pra.para.11-12.
} 
almaları ve yağma ve hırsızlık fiillerini, kültürel ve dini anıtların tahrip edilmesini ve çocukların askere alınmasını kınamış, bu sayılan fillerin aynı zamanda Uluslararası Ceza Mahkemesi'nin Statüsü kapsamında suç teşkil ettiğini ve faillerinin hesaba çekileceğini ifade edilerek, ${ }^{33}$ Mali'deki durumun uluslararası barış ve güvenliği tehdit ettiğini tespit etmiştir. ${ }^{34}$

Kararda Konsey, BM Sözleşmesinin VII. bölümü çerçevesinde hareket ettiğini ifade ederek, Mali'deki isyancı gruplardan bütün terörist örgütlerle ilişkilerini kesmelerini, aksi takdirde bu gruplara karşı yaptırım uygulayacağını bildirmiş ${ }^{35}$ ve geçici hükümetten, isyancı gruplardan ve Kuzey Mali'deki yerel halkın meşru temsilcilerinden mümkün olduğunca süratli bir şekilde kabul edilebilir, Mali’nin bağımsızlığı, birliği ve ülkesel bütünlüğünü esas alan politik bir çözüme ulaştırıcı gerçekçi bir görüşme sürecini başlatmalarını talep etmiştir. ${ }^{36}$

Konsey kararında ayrıca, Kuzey Mali'deki bütün gruplardan, tüm insan hakları ve insanc1l hukuk ihlallerini, özellikle sivil halka karşı kasten yapılan saldırıları, cinsel saldırıları, çocukların askere alınması ve çatışmalara sokulmasının durdurulmasını, bu konulardaki bütün eski kararlarını da hatırlatarak istemiştir. $^{37}$

\section{Güvenlik Konseyi'nin S/RES/ 2085 (2012) Sayılı Kararı}

BM Güvenlik Konseyi 20.12.2012 tarih ve S/RES/ 2071 (2012) sayılı kararında Kuzey Mali'deki durumun Sahel bölgesinin ve uluslararast toplumun istikrart için tehdit oluşturduğunu, terörist grupların ve suç örgütlerinin Kuzey Mali'ye iyice yerleşmiş olmalarının Mali'deki sivil halk için ciddi bir tehdit oluşturduğunu ifade etmiştir. ${ }^{38}$

Konsey önceki kararında olduğu gibi, bu kararında da ülkedeki güvensizlik ortamı ve Sahel bölgesinde gittikçe kötüleşen insani kriz hakkında endişelerini dile getirmiş, silahlı ve ayrılıkçı grupların ve suç örgütlerinin bölgede faaliyetlerinin artmasının ve gerek bölge içinde gerekse bölge dışında silah kullanımının artmasının, bölgedeki devletlerin barış ve güvenliğini tehdit etmesinin devam ettiğini tespit etmiştir. ${ }^{39}$

33 S/RES/2071 (2012), pra.para.15.

34 S/RES/2071 (2012), pra.para.17.

35 S/RES/2071 (2012), op.para.3.

36 S/RES/2071 (2012), op.para.4.

37 S/RES/2071 (2012), op.para.5.

38 S/RES/2085 (2012), pra. para. 3.

39 S/RES/2085 (2012), pra. para.5. 
Kararda askerlerin ve diğer güvenlik güçlerinin geçici hükümetin işlerine müdahale etmesi kınanarak, Mali'de yeniden anayasal sistemin ve demokratik hükümetin oluşturulmasının zaruretine dikkat çekilmiş ve yeniden seçimlerin yapılması için Genel Sekreterin özel temsilcisinin çalışmakta olduğu hatırlatılmıştır. ${ }^{40}$

Kararda, Kuzey Mali'de sivillere özellikle çocuklar ve kadınlara karşı şiddet uygulanması, öldürmeler, rehin almalar, yağmalamalar, hırsılılılar, tarihi ve kültürel anıtların yıkılması, çocukların askere alınarak silahlı çatışmalara katılmak üzere cephelere gönderilmesi gibi filler sayılmış ve bu fiillerin bazılarının Uluslararası Ceza Divanı'nın statüsüne göre suç teşkil edebileceğini ve bu fiillerin faillerinin yargılanacağı belirtilerek, Geçici Mali Hükümeti'nin 0cak 2012'den itibaren olan olayları 13.07.2012 tarihinde Uluslararası Ceza Divanı'na taşıdığı hatırlatılmıştır. ${ }^{41}$

Mali Geçici Hükümeti yine 12.10.2012 tarihli mektupta Kuzey Mali'de savaş suçu, insanlığa karşı suçları işleyen kişilerin mahkemeye çıkartılması için ulusal ve uluslararası alanda gerekli çalışmaların yapılmasını istedi. ${ }^{42}$

Konsey özellikle Mali'de birbiriyle bağlantılı bu krizleri çözmeye ilişkin ana sorumluluğun Mali idaresine ait olduğunu ve uygulanabilir çözümün sadece Mali idarecilerinin katılımıyla mümkün olabileceğini ifade etmiştir ${ }^{43}$.

Konsey bütün bu olgulara dayanarak Mali'deki durumun uluslararası barış ve güvenliği tehdit ettiğini tespit etmiş ve BM Sözleşmesi VII. bölüm kapsamında hareket ettiğini ifade ederek ${ }^{44}$ aşağıdaki eylem planını ortaya koymuştur.

\subsection{Politik Süreç}

Konsey Mali Geçici Hükümeti'nden, Nisan 2013 tarihine kadar ya da mümkün olan en kısa süre içinde başkanlık ve parlamento seçiminin yapılmasını talep etmiştir. ${ }^{45}$

Konsey bütün isyanc1 gruplardan İslamc1 radikal örgütlerle irtibatı kesmesini, aksi takdirde müeyyide uygulayacağını ${ }^{46}$ hükümetin de radikal İslamcı gruplarla ilişkisi olmayan veya ilişkisini kesmiş bulunan ve ülke bütünlügünü kayıtsız

\footnotetext{
40 S/RES/2085 (2012), pra. para.4.

41 S/RES/2085 (2012), pra. para.6.

42 S/RES/2085 (2012), pra. para.7.

43 S/RES/2085 (2012), pra. para.14.

44 S/RES/2085 (2012), pra. para.15.

45 S/RES/2085 (2012), op.para. 1.

46 S/RES/2085 (2012), op.para. 2.
} 
şartsız kabul eden bütün taraflarla, makul bir çerçeve içinde görüşme masasına oturmasını ve bu görüşmeler çerçevesinde uzun zamandır Kuzey bölgesinde yaşayan sivil halkın taleplerini de nazara alarak bir araya gelmesini istemiştir. ${ }^{47}$

Ayrıca kararda ordudan geçici hükümetin işine karışmaması istenmiş, bu müdahalenin Mali'de anayasal düzenin oluşturulmasına mani olacak dereceye varması halinde ise bu kişilere karşı gerekli yaptırımlara başvurulacağı ifade edilmiştir. $^{48}$

\subsection{Güvenliğe İlişkin Süreç}

Bu karar kapsamında, insancıl hukuka ve uluslararası insan hakları normlarına uygun bir şekilde yönetimin sağlanması, Mali'nin birliği, ülke bütünlüğü ve bağımsızlığını temin etmeye yönelik bütün önlemleri almakla görevli olan ve bir y1l süreyle görev yapacak Afrika önderliğinde bir misyon (AFISMA) kurmaya karar verilmiştir. ${ }^{49}$

Bu misyonun görevi, Mali güvenlik birimlerinin yeniden yapılandırılmasına destek olmak ${ }^{50}$, Mali hükümetine Kuzey Mali'nin yeniden kontrol altına alınması için gerekli bütün yardımların yapılması ${ }^{51}$; sivil halkı korumada destekçi olmak; ${ }^{52}$ sivillerce yönetilen insani yardımların yapılabilmesi, ülke içinde yurtlarından çıkartılmış veya mülteci olmuş olan sivillerin geri dönüşlerine yardımcı olmak amacıyla güvenli bölgeler oluşturmak ve bu konuda insani yardım kuruluşlarıyla işbirliği yaparak destek olmak şeklinde sıralanmıştır. ${ }^{53}$

\subsection{Uluslararası Destek}

Konsey üye devletlerden, bölgesel ve uluslararası örgütlerden, AFISMA'y1 faaliyetlerinde desteklemelerini istemiştir. ${ }^{54}$ Konsey ayrıca bütün taraflardan Mali'deki insani yardım personelinin ve insani yardım malzemelerinin güvenliğinin sağlanmasını ve bu yardımların muhtaçlara engellenmeden ve güvenli bir şekilde ulaşması için gerekli önlemleri almalarını ve destekleri sağlamalarını talep etmiştir. ${ }^{55}$

47 S/RES/2085 (2012), op.para. 3.

48 S/RES/2085 (2012), op.para. 4.

49 S/RES/2085 (2012), op.para. 9.

50 S/RES/2085 (2012), op.para. 9/a.

51 S/RES/2085 (2012), op.para. 9/b.

52 S/RES/2085 (2012), op.para. 9/c.

53 S/RES/2085 (2012) op.para.. 9/e.

54 S/RES/2085 (2012), op.para. 14.

55 S/RES/2085 (2012), op.para. 16. 


\section{4. İnsan Hakları}

Kararda Mali'deki sivillerin korunmasının ana sorumluluğunun Mali hükümetine ait olduğu ${ }^{56}$ bu konuda BM, bölgesel ve uluslararası örgütler ve üye devletlerce yapılacak her türlü desteğin insancıl hukuk ve uluslararası insan hakları ve uluslararası mülteci hukukuna uygun olması gerektiği ifade edilmiştir. ${ }^{57}$

Konsey, AFISMA'dan, ağır insan hakları ihlallerini işleyen ve insancıl hukuk ihlallerini ihlal edenleri, Uluslararası Ceza Mahkemesi önüne çıkarmak için ulusal ve uluslararası alanda gerekli gayretleri göstermesini talep etmiştir. ${ }^{58}$

\section{Güvenlik Konseyi’nin S/RES/2100 (2013) Sayılı Kararı}

Güvenlik Konseyi 25 Nisan 2013 tarihinde aldığı S/RES/2100(2013) sayılı kararında 10.01.2013 tarihinde radikal silahlı gruplarca Kuzey Mali’ye yönelik olarak sürdürülen saldırıları kınamış, ${ }^{59}$ serbest seçimlerin derhal yapılması ve demokratik bir hükümet kurulmasının gerekliliğini vurgulayarak, ${ }^{60}$ ülkedeki gıda maddesi sıkıntısı ve insani yardım durumunun ciddiyetine dikkat çekmiş, yardımların muhtaçlara ulaştırılmasına engel olunması, ülkedeki silahlı grupların varlığ ve faaliyetleri ile mayınlar ve bölgede silahların yayılmasının bölge devletlerinin barışını, güvenliğini ve istikrarını tehdit etmekte olduğunu ifade etmiştir. ${ }^{61}$

Konsey Mali'deki gruplar ya da kişiler tarafindan Kuzey Mali'de işlenen insan hakları ve insancıl hukuk ihlallerini, keyfi tutuklamaları, hapisleri, idamları, cinsel taciz ve tecavüzleri, çocukların zorla askere alınmasını, okullara ve hastanelere saldırılmasını, tarihi ve kültürel mirasların tahrip edilip yıkılmasını kınamıştır. ${ }^{62}$ Konsey ayrıca Sahel bölgesinde sınır aşan örgütlü suçlardan doğan ciddi tehditler ve bunlar ile terörizm arasında artan ilişki hakkında endişelerini dile getirmiştir ${ }^{63}$.

Konsey yukarda yer alan hususları belirttikten sonra, Mali' deki durumun hala uluslararası barış ve güvenliği tehdit etmekte olduğunu tespit etmiştir.

Konsey BM Sözleşmesi’nin VII. bölümü çerçevesinde bağlayıcı karar aldığını açıkça ifade ederek, Mali'deki bütün silahlı gruplardan silahlarını bırakmalarını, düşmanlıktan vazgeçmelerini, terör örgütleriyle irtibatlarını kesmelerini

\footnotetext{
56 S/RES/2085 (2012), op.para. 17.

57 S/RES/2085 (2012), op.para. 18.

58 S/RES/2085 (2012), op.para. 19.

59 S/RES/2100(2013), pra. para.4.

60 S/RES/2100(2013), pra. para.6.

61 S/RES/2100(2013), pra. para.7.

62 S/RES/2100(2013), pra. para.9.

63 S/RES/2100(2013), pra. para.12.
} 
ve ülkenin birlik ve bütünlüğünü herhangi bir şart ileri sürmeksizin tanımalarını talep etmiştir. Ayrıca Mali geçici hükümetinden bütün tarafları görüşme masasına çağırmasın $1^{64}$ ve mümkün olabilecek en kısa zamanda bütün tarafların da katıldığ serbest seçimleri düzenlemesini istemiştir. ${ }^{65}$

Bu kararın önemli bir tarafı da, Mali'de barış ve güvenliği sağlamak için 11.200 askerden ve 1440 polisten oluşacak olan bir misyon (the United Nations Multidimensional Integrated Stabilization Mission in Mali, MINUSMA) kurulmasını düzenlemiş olmasıdır. ${ }^{66}$

MINUSMA, ülkede istikrarın sağlanması için, ülkenin bütününde devletin idari yapısının yeniden tesis edilmesi için hükümete destek vermek; ${ }^{67}$ silahlı unsurların sivil yerleşim bölgelerine geri dönüşleri konusunda yardım etmek, ${ }^{68}$ eski savaşçıların terhisi edilmesi ve yeniden orduya dahil edilmesi ve milislerin dağıtılması ve yeni savunma gruplarının oluşturulması konusunda hükümete yardım etmekle, görevli k1lınmıştır. ${ }^{69}$

MINUSMA ayrıca, anayasal düzenin yeniden tesisi, demokratik hükümetin oluşturulması ve ulusal birliğin tesisi konusunda hükümete yardım edecek, ${ }^{70}$ gerekli lojistik ve teknik desteği sağlayarak serbest seçimlerin yapılmasını destek verecek, ${ }^{71}$ görev bölgesi içinde ve sahip olduğu imkânlar çerçevesinde, geçici hükümetin sorumluluk alanlarına zarar vermeden sivilleri fiziki zararlardan koruyacak, ${ }^{72}$ silahlı çatışmalardan zarar gören kadınlar ve çocuklara özel koruma sağlayacak, cinsel suçlardan mağdur olanların özel ihtiyaçlarını da dikkate alacaktır. ${ }^{73}$

MINUSMA insan hakları gözlemcilerinin bütün ülkede desteklenmesi, ${ }^{74}$ insani yardım ilkeleri çerçevesinde sivil halka yardım sunan insani yardım örgütlerinin yaptığı insani yardımların yerlerine ulaştııılması ve mültecilerin rızalarıyla geri dönüşlerinin sağlanması için güvenli bölgelerin oluşturulması konusunda Mali hükümetine yardım edecektir. Ayrıca kültür varlıklarının korunması için

64 S/RES/2100(2013), op. para.4.

65 S/RES/2100(2013), op. para.3.

66 S/RES/2100(2013), op. para.7.

67 S/RES/2100(2013), op. para.16/a-ii.

68 S/RES/2100(2013), op. para.16/a-ii.

69 S/RES/2100(2013), op. para.16/a-iv.

70 S/RES/2100(2013), op. para.16/b-i.

71 S/RES/2100(2013), op. para.16/b-iii.

72 S/RES/2100(2013), op. para.16/c-i.

73 S/RES/2100(2013), op. para.16/c-ii.

74 S/RES/2100(2013), op. para.16/d-iii. 
merkezi idareye destek sağlayacak ${ }^{75}$ ulusal ve uluslararası yargı kapsamında hükümete yardım edecektir. ${ }^{76}$ BM Barış Misyonu Mali'nin her yerinde gerçekleştirilen insan hakları ihlallerini ya da insancıl hukuk ihlallerini takip edecek, bu konudaki araştırmalara yardım edecek, meydana gelebilecek ihlallere engel olacaktır. ${ }^{77}$ Konsey Mali geçici hükümetinden ağır insan hakları ihlalleri ve ağır insancıl hukuk ihlalleri yapanların yargılanması ve Uluslararası Ceza Yargısı önüne çıkartılması konusunda mahkeme ile birlikte çalışmasını istemiştir. ${ }^{78}$

Konsey MINUSMA'ya görevli bulunduğu bölgede, görevleri yerine getirmek için gerekli olan bütün araçları kullanma yetkisi vermiştir. ${ }^{79}$ Ayrıca Fransız birliklerini de kendi imkanları dahilinde ve görevli olduğu bölge içinde, gerekli olduğunda MINUSMA misyonunu göreve başlamasından görev süresinin bitimine kadar, tehdit altında olduğu her durumda ona her türlü desteği sağlamak konusunda yetkilendirmiştir. ${ }^{80}$

\section{Güvenlik Konseyi’nin S/RES/2164 (2014) Sayılı Kararı}

Güvenlik Konseyi 25.06.2014 tarihinde aldığ1 S/RES/2014(2014) sayılı kararında, barışın güven altına alınması temel prensibiyle özellikle tarafların onayı, tarafsızlık ve meşru müdafaa ve misyonun savunması dışında kuvvet kullanılmamasına vurgu yapmıştır. ${ }^{81}$

Kararda Kuzey Mali'deki güvenlik problemi ile Sahel bölgesinde terör örgütlerinin faaliyetlerini sürdürmelerinin bölgede barış ve güvenliği tehdit ettiğ $i$ tespit edilmiştir. Ayrıca kararda terör örgütlerinin Kuzey Mali'de ve bölgede gerçekleştirdiği insan hakları ihlalleri, sivillere karşı şiddet eylemleri, özellikle kadın ve çocuklara yönelik olanları şiddetle kınanmıştır. ${ }^{82}$

Konsey Sahel bölgesinde sınır aşan organizasyon gücüne sahip suç örgütlerinin ${ }^{83}$ ve terör örgütlerinin ${ }^{84}$ oluşturduğu tehdidin sınır aşan özelliğini dile getirmiş ve bu tehditlerle mücadele için tutarlı bir bölgesel tutumun gerekliliğine vurgu yapmıştır. ${ }^{85}$

\footnotetext{
75 S/RES/2100(2013), op. para.16/f.

76 S/RES/2100(2013), op. para.16/g.

77 S/RES/2100(2013), op. para.16/d-ii.

78 S/RES/2100(2013), op. para.27.

79 S/RES/2100(2013), op. para.17.

80 S/RES/2100(2013), op. para.18.

81 S/RES/2164 (2014), prae.para.3.

82 S/RES/2164 (2014), prae.para.11.

83 S/RES/2164 (2014), prae.para.16.

84 S/RES/2164 (2014), prae.para.14.

85 S/RES/2164 (2014), prae.para.15.
} 
Kararda Sahel bölgesinde silahlı grupların faaliyetleri, mayınlar ve bölgede silahların yayılması bölgedeki devletlerin istikrarını sarstığı tespit edilmiş ve yine bölgede devam eden gıda maddesi sıkıntısı ve insani acil yardım gerekliliği ve güvensiz ortam sebebiyle insani yardımların engellenmesi sebebiyle bölgede uluslar arası barış ve güvenliği tehdit edildiği belirtilmiştir. ${ }^{86}$

Kararda ayrıca, insan hakları ihlalleri, insancıl hukuk ihlalleri, yargısız idamlar, keyfi tutuklamalar ve okullara yapılan saldırılar şiddetle kınanarak, bütün taraflardan bu eylemlerine son vermeleri ve uluslararas hukuk sorumluluklarına riayet etmeleri talep edilmiştir. ${ }^{87}$ Konsey bu fiillerin bazılarının Roma Statüsüne göre suç teşkil edebileceğini ve sorumluların Uluslararası Ceza Mahkemesi'nde yargılanacağını bildirmiştir. ${ }^{88}$

Komisyon Mali'deki güvenlik ve istikrarın sağlanması konusunda ana sorumluluğun Mali idaresinde olduğunu önemle vurgulamıştır. Bu bakımdan Mali Güvenlik ve Savunma güçlerinin sivil idarenin emri altında olmasının önemi belirtilmiştir. ${ }^{89}$

Güvenlik Konseyi bu kararında da Mali'deki durumun hâlâ açık bir şekilde uluslararası barış ve güvenliği tehdit ettiği tespitini yapmıştır. ${ }^{90}$

Kararın operasyonel kısmında Konsey, taraflardan bağlayıcı olarak, Mali'de istikrar ve barışın sağlanması için bütün tarafların ateşkes anlaşmasına uymasın1 ve ülkenin bağımsızlığını, birliğini ve bütünlüğünün sağlanması esasına yönelik görüşmelere katılmalarını; hükümetin özellikle terör örgütleriyle ilişkisini kesmiş olan Kuzey'deki isyancı grupların bu görüşme masasına dahil edilmesi için gerekli çalışmayı yapması ve grupların da diyaloğa hazır olmalarını; ${ }^{91}$ bütün grupları MINUSA misyonuna silahlı grupların silahsızlanma, silahı bırakıp mevcut birliklere entegre olma konusunda yapılan çalışmayı desteklemesini; ${ }^{92}$ Mali idaresinin insan hakları ihlalleri ve uluslararası insancıl hukuk ihlalleriyle mücadele etmesini; suçluların cezasız kalmaması için gerekli çalışmaları yapmas1 Uluslararası Ceza Mahkemesi'yle işbirliği yapmasını talep etmiştir. ${ }^{93}$

86 S/RES/2164 (2014), prae.para.18.

87 S/RES/2164 (2014), prae.para.19.

88 S/RES/2164 (2014), prae.para.20.

89 S/RES/2164 (2014), prae.para.21.

90 S/RES/2164 (2014), prae.para.27.

91 S/RES/2164 (2014), ope.para.1-4.

92 S/RES/2164 (2014), ope.para.5.

93 S/RES/2164 (2014), ope.para.8. 
Konsey ayrıca sayılan bu hususların yerine getirilmesini sağlamak amaciyla MINUSMA'ya mümkün olan bütün araçları kullanmak yetkisi vermiştir. ${ }^{94}$

\section{Güvenlik Konseyi’nin S/RES/2227 (2015) Sayılı Kararı}

23.05.2014 tarihinde Mali'de taraflar arasında ateşkes antlaşması imzalandı. 19.02.2015 ve 24.07.2014 tarihlerinde de taraflar "Düşmanlıkların Sonlandırılmas1 Açıklaması"nda bulundular. 05.06.2015 tarihinde hükümet ile "Coordination" adlı silahlı gruplar arasında "Düşmanlıkların Durdurulmasına İlişkin Güvenlik Sözleşmesi" imzaland $1 .{ }^{95}$ Bütün bunlar Güvenlik Konseyi tarafından Mali'deki iç savaşın sonlandırılması yolunda olumlu bir gelişme olarak değerlendirildi. ${ }^{96}$

Konsey Sahel bölgesinde yayılan sınır aşan organize suçlar, özellikle silah, uyuşturucu ve insan ticareti ve bunların terörizm maksatlı kullanılmasından ciddi endişe duyduğunu ifade etmiş ${ }^{97}$, fidye ve politik kazanımlar için insan kaçırmak ve rehin alma fiillerini şiddetle kınamıştır. ${ }^{98}$

Konsey belirli bir din, 1rk ya da medeniyet ile terörizmi ilişkilendirmemektedir. ${ }^{99}$ Konsey bütün insan hakları ihlallerini, insanc1l hukuk ihlallerini, özellikle yargılama olmaksızın toplu idamları, keyfi gözaltı ve tutuklamaları, esirlere kötü muamele yapılmasını, cinsel içerikli suçları, çocukların askere alınmasını ve çatışmalarda kullanılmasını, hastanelere ve okullara saldırılmasını şiddetle kınayarak, bütün taraflardan okulların sivil karakterini insancıl hukuk bağlamında dikkate almalarını talep etmiştir. ${ }^{100}$ Kararda bu tür eylemleri yapanların yargılanacakları ve bu eylemlerin bazılarının Uluslararası Ceza Divanı Statüsü'ne göre suç sayılacağı hatırlatılmaktadır. ${ }^{101}$

Konsey kararda ülkede hâlâ devam eden gıda sıkıntısı ve insani krizin ciddi endişeler oluşturduğunu ve mevcut güvenlik sorunu sebebiyle muhtaçlara yardımların ulaştırılamamasının endişe verici olduğunu ifade etmiştir. ${ }^{102}$

Kararda "Barışı Koruma Gücünü (MINUSMA)" hedef alan saldırıların uluslararası hukuka göre savaş suçu teşkil ettiği ifade edilmektedir. ${ }^{103}$ Mali'de

\footnotetext{
94 S/RES/2164 (2014), ope.para.12.

95 S/RES/2227 (2015), prae.para.10.

96 S/RES/2227 (2015), prae.para.5.

97 S/RES/2227 (2015), prae.para.18.

98 S/RES/2227 (2015), prae.para. 19.

99 S/RES/2227 (2015), prae.para.15.

100 S/RES/2227 (2015), prae.para.20.

101 S/RES/2227 (2015), prae.para.21.

102 S/RES/2227 (2015), prae.para.27.

103 S/RES/2227 (2015), prae.para.12.
} 
faaliyet içinde olan terör gruplarının faaliyetleri bölgede barış ve güvenliği tehdit etmektedir. Bunun yanında terör gruplarının sivil kişilere özellikle kadın ve çocuklara yönelik Kuzey Mali'de işledikleri insan hakları ihlalleri barış ve güvenliği bölgede tehdit etmektedir ${ }^{104}$. Ayrıca Konsey'e göre terörün Sahel bölgesindeki sınır aşan özelliği büyük endişe kaynağı olmaya devam etmektedir. ${ }^{105}$

Bütün bu sayılan hususları birlikte değerlendiren Konsey Mali'deki durumu önceki kararlarında olduğu gibi uluslararası barış ve güvenliği tehdit eder nitelikte değerlenirmiş ve BM Sözleşmesi'nin VII. bölümü çerçevesinde hareket ettiğini belirterek, aşağıdaki kararları almıştır:

Konsey kararda silahlı gruplardan ("Plateforme" ve "Coordination") ve hükümetten barışa ilişkin antlaşmalara ${ }^{106}$ ve ateşkes anlaşmasına ${ }^{107}$ sadık kalmalarını istemiş, andlaşmaların uygulanmasını tehlikeye atanlara, engelleyenlere, MINUSMA ya saldıranlara veya tehdit edenlere karşı yaptırım uygulanacağını bildirmiştir. ${ }^{108}$

Kararda Mali hükümetinden suçluların yargılanması ve bu konuda Uluslararası Ceza Divanı ile işbirliği yapması istenmiştir. ${ }^{109}$

Kararda MINUSMA'ya, ateşkese riayet edilmesinin sağlanması, Mali'deki barış sürecinin istikrarın yerleşmesinin desteklenmesi, sivillerin korunması, insan haklarının korunması ve geliştirilmesi, BM personelinin güvenliğinin sağlanması, kültür varlıklarının korunmasına destek olma görevleri verilmiştir ${ }^{110}$.

Konsey ayrıca Sahel bölgesindeki devletlerden özellikle uluslararası terörizme karşı koordineli bir şekilde mücadele etmelerini talep etmiştir. ${ }^{111}$

\section{Güvenlik Konseyi'nin S/RES/2295(2016) Sayılı Kararı}

Güvenlik Konseyi 29.07.2016 tarihinde aldığ S/RES/2295(2016) sayılı kararında ilk kararlarında uluslararası barış ve güvenliği tehdit eder olarak değerlendirdiği aynı olayların hâlâ devam etmekte olduğunu, özellikle birçok terör örgütünün Mali'de hâlâ faaliyetlerini sürdürüyor olmasına dayanarak Mali'deki mevcut durumun uluslararası barış ve güvenliği tehdit etmekte olduğunu tespit etmiştir. ${ }^{112}$

\footnotetext{
104 S/RES/2227 (2015), prae.para.14.

105 S/RES/2227 (2015), prae.para.18.

106 S/RES/2227 (2015), op.para.1.

107 S/RES/2227 (2015), op.para.2.

108 S/RES/2227 (2015), op.para.3.

109 S/RES/2227 (2015), op.para.5.

110 S/RES/2227 (2015), op.para.14.

111 S/RES/2227 (2015), op.para.29.

112 S/RES/2295 (2015), prae.para.16.
} 
Konsey, BM Sözleşmesi'nin VII. bölümü kapsamında hareket ettiğini ifade ederek, hükümetten ve silahlı grupların koalisyonundan ("Plateforme" ve Coordination") Mali'de barışın sağlanması için yapıcı bir politik irade ile çalışarak Mali'de uzlaşı ve barışın sağlanması anlaşmasının icra edilmesini sağlamak ${ }^{113}$ yolunda gerekli adımları atmalarını, ${ }^{114}$ aralarında yaptıkları diğer anlaşmalara uymaların1 ${ }^{115}$ talep etmektedir. Ayrıca kararda bütün silahlı gruplardan silahlarını bırakmaları, düşmanlıktan vazgeçmelerini, terör örgütleriyle irtibatlarını kesmelerini, ülke bütünlügüne ve birliğine riayet etmelerini, ${ }^{116}$ insanc1l hukuktan kaynaklanan yükümlülüklere dikkat etmeleri istenmektedir. ${ }^{117}$

Konsey bu kararında özellikle bölgedeki devletlerden, Sahel, Batı Afrika ve Mağrib Devletlerinden, bölgesel örgütlerden, sınır aşan faaliyetlerde bulunan ve Sahel bölgesini sığınma yeri olarak kullanan terör örgütlerine karşı işbirliği içinde olmalarını istemiştir. ${ }^{118}$

Güvenlik Konseyi'nin Kararlarının Uluslararası Hukuk Çerçevesinde Değerlendirilmesi

Güvenlik Konseyi’nin Mali krizine ilişkin aldığı kararlarında, BM Sözleşmesinin 39.maddesi kapsamında uluslararası barış ve güvenliğin tehdit edildiği tespitine dayanak teşkil eden olayları aşağıdaki başlıklar altında toplamak mümkündür:

\section{Terör}

Mali krizinin doğurduğu en önemli etki şüphesiz ülkedeki merkezi otorite boşluğu sebebiyle bölgeye terör örgütleri ve suç örgütlerinin hâkim olmasıdır. Daha önce uluslararası toplum tarafindan terör, global bir tehdit olarak algılanmış ve herhangi bir yer bağlantısı olmaksızın terör, uluslararası barış ve güvenliği tehdit eden bir unsur olarak tespit edilmişti. Öncelikle Konsey terörizmle mücadele için daha önce aldığı 1267 (1999) ve 1989 (2011) kararlarını hatırlatmış, Bölgede ve Kuzey Mali'de terörist grupların tehditlerinin artışının endişe verici olduğunu, terörizmin her formu ve şekliyle barış ve güvenliği sarsan ciddi bir tehdit oluşturduğunu ifade etmiştir. ${ }^{119}$ Konsey ayrıca Sahel bölgesinde sınır aşan örgütlü

\footnotetext{
113 S/RES/2295 (2015), ope.para.1.

114 S/RES/2295 (2015), ope.para.2.

115 S/RES/2295 (2015), ope.para.3.

116 S/RES/2295 (2015), ope.para.5.

117 S/RES/2295 (2015), ope.para.37.

118 S/RES/2295 (2015), ope.para.47.

119 S/RES/2056 (2012), pra.para 11.
} 
suçlardan doğan ciddi tehditler ve bunlar ile terörizm arasında artan ilişkinin endişe verici olduğunu belirterek, ${ }^{120}$ Kuzey Mali'deki güvenlik problemi ile Sahel bölgesinde terör örgütlerinin faaliyetlerin devamını birlikte değerlendirerek bölgede barış ve güvenliğin tehdit altında olduğunu tespit etmiştir. ${ }^{121}$

Konsey bütün üye devletleri özellikle Sahel ve Mağrip devletlerini, terör gruplarının sınırlardan geçişlerine engel olmaya ve Sahel bölgesinde kendilerine güvenli liman arayışlarına karşı önlem almaya davet etmiştir. ${ }^{122}$

\section{Tarihi ve Kültürel Varlıklar}

Konsey bölgedeki tarihî eserlerin, kültürel ve kutsal yerlerin terör örgütleri tarafindan tahrip edilmesi ve bu eserlere zarar verilmesi fillerini sert bir şekilde kınamış ${ }^{123}$ ve dini, tarihi anıtlara yapılan saldırıların Cenevre Sözleşmesi II Nolu ek protokolü ve Mali'nin taraf olduğu Uluslararası Ceza Mahkemesi Roma Statüsü’nün çerçevesinde değerlendirileceğini belirtmiştir. Ayrıca Konsey bütün tarafları dünya kültür mirasının korunmasını sağlamak konusunda uygun önlemleri almaya davet etmiştir. ${ }^{124}$

\section{İnsani Yardımlar ve İnsani Yardım Örgütleri}

Çoğu iç savaşlarda olduğu gibi Mali'de özellikle de kuzey bölgesinde bir çok sivil çatışmalardan kaçıp yerlerini terk etmek zorunda kalarak yardıma muhtaç duruma gelmiştir. Diğer taraftan kriz sebebiyle ülkede ekonomik durum bozulmuş, gıda sıkıntısı çekilmeye başlanmıştır. Gerekli gıda maddelerinin bulunamamasının yanında güvenlik sebebiyle gerekli gida maddelerinin muhtaçlara ulaştırılamaması endişe verici hale gelmiştir. ${ }^{125}$ Konsey çatışmaların bütün taraflarından, ülkedeki insani durumun kötüleşmesi, yurtlarından çıkartılanlar ve mültecilerin sayısındaki artış konusunda endişelerini dile getirerek bu kişilere ayrım gözetmeksizin insani yardım malzemelerinin herhangi bir engellemeye maruz kalmaksızın zamanında ulaşması ve insani yardım personelinin güvenliğinin sağlanması için, uluslararası hukuk ve uluslararası insancıl hukuk çerçevesinde gerekli bütün önlemleri almalarını talep etmiştir. ${ }^{126}$

120 S/RES/2100(2013), pra. para.12.

121 S/RES/2164 (2014), prae.para.11.

122 S/RES/2164 (2014), ope.para.30.

123 S/RES/2056 (2012), pra.para 13.

124 S/RES/2056 (2012), op.para 16.

125 S/RES/2100(2013), pra. para.7; S/RES/2227 (2015), prae.para.27.

126 S S/RES/2056 (2012), op.para 14; S/RES/2085 (2012), op.para. 16; S/RES/2056 (2012), pra. para 12; S/RES/2085 (2012), op.para. 16. 


\section{Siviller, Kadınlar ve Çocukların Durumu}

Mali'deki iç çatışmalar sebebiyle en çok mağdur olan gruplardan birisi de şüphesiz, siviller, kadınlar ve çocuklardır. Krizin başından itibaren siviller sürekli saldırıya uğramış, yerlerinden çıkartılarak zorunlu yerleştirmeye tabi tutulmuşlardır. ${ }^{127}$ Çocuklar zorla askere alınmış ve çatışmalara zorlanmışlardır. ${ }^{128}$ Bunun yanında yine kadınlar cinsel saldırılara maruz kalmışlardır. Öte yandan silahlı kişiler ve gruplar okullara ve hastanelere saldırmışlar, alışılmamış idamlar, keyfi tutuklamalar ve hapisler vuku bulmuştur. ${ }^{129}$ Özellikle Kuzey Mali, insan hakları ve insanc1l hukuk ihlallerinin yoğunlaştığı bir alana dönüşmüştür.

Güvenlik Konseyi kararlarında, insan hakları ihlalleri, insanc1l hukuk ihlalleri, yargısız idamlar, keyfi tutuklamalar, cinsel içerikli suçlar, çocukların askere alınarak çatışmalarda kullanılması, hastanelere ve okullara saldırı fiilleri şiddetle kınanmış ve bütün taraflardan bu eylemlerini sona erdirmeleri talep edilmiştir. ${ }^{130}$ Konsey bu fiillerin bazılarının Roma Statüsü’ne göre suç teşkil edebileceğini ve bu fillerin faillerinin Uluslararası Ceza Mahkemesi'nde yargılanacağını bildirmiştir. ${ }^{131}$

\section{Mülteciler}

Mali'de çatışma bölgelerinden kaçan sivillerin bölgede oluşturduğu mülteci sorununa dair Konsey endişelerini dile getirmiş ${ }^{132}$ ve Cezayir, Burkina Faso, Moritanya, Nijer gibi komşu ülkelerin mültecilere ve insani yardımlara yönelik sınırı açık tutma hususundaki ortak politikalarını desteklemiştir. ${ }^{133}$ Ayrıca bu devletlerden Mali hükümetine Kuzey Mali'nin yeniden kontrol altına alınması için gerekli bütün önlemlerle yardım etmelerini istemiştir. ${ }^{134}$

Konsey ayrıca, sivillerce yönetilen insani yardımların yapılabilmesi, ülke içinde yurtlarından çıkartılmış veya mülteci olmuş sivillerin geri dönüşlerine yardımcı olmak amacıyla güvenli bölgelerin oluşturulması ve bu konuda insani yardım kuruluşlarıyla işbirliği yaparak Mali hükümetine destek verilmesini karara bağlamıştır. ${ }^{135}$

127 S/RES/2056 (2012), op.para 13.

128 S/RES/2071 (2012), op.para.5; S/RES/2085 (2012), pra. para.6.

129 S/RES/2100(2013), pra. para.9.

130 S/RES/2164 (2014), prae.para.19; S/RES/2164 (2014), prae.para.11.

131 S/RES/2164 (2014), prae.para.20.

132 S/RES/2056 (2012), pra.para 12.

133 S/RES/2056 (2012), op.para 15.

134 S/RES/2085 (2012), op.para. 9/b.

135 S/RES/2085 (2012) op.para.. 9/e. 


\section{Konsey Kararında Uluslararası Barış Kavramının Anlamı}

Uluslararası barışın korunması konusunda ana sorumluluk BM Sözleşmesi'nin 24. maddesi uyarınca Güvenlik Konseyi'ne verilmiştir. Güvenlik Konseyi kararlarında ilgili krizin 39. maddede sayılan durumlardan birisini (uluslararas1 barışın tehdit edilmesi, barışın bozulması veya saldırı hali) oluşturup oluşturmadığını tespit etmektedir. Konsey önce maddi olguları açıklamakta, daha sonra da bu olgulara dayanarak, krizin uluslararası barış ve güvenliğin tehdit ettiğini tespit etmektedir. Ancak bu sayılan sebeplerden hangisinin 39. maddeye göre barış tehdidi tespitine esas alındığı çoğu zaman anlaşılamamaktadır.

Burada 39. madde kapsamında barış tehdidi tespiti yapılırken, karara esas teşkil eden "barış" kavramı, devletler arasındaki silahlı çatışmaların yokluğunu ifade eden "negatif barış"1 mı, ifade etmektedir, yoksa insan hakları ve insancıl hukuk kurallarına riayet edilen bir iç düzenin varlığını ifade eden pozitif barış da bu kapsamda değerlendirilebilecek midir, sorusunun cevabı etrafinda öğretide fikir birliği bulunmamaktadır. Barış kavramı BM Sözleşmesi'nin merkezinde yer almakla birlikte, 39. maddede yer aldığı şekliyle "barış" kavramının "pozitif barış" olarak da anlaşılması zor görülmektedir. Zaten Konsey kararları incelendiğinde bu konuda dikkatli bir usul takip edildiği anlaşılmaktadır. Irak, Somali, Libya hakkında verilen kararlarda olduğu gibi, Konsey iç çatışmalar sebebiyle ortaya çıkan krizler iç hukuku ilgilendirdiğinden dolayı, genellikle bu krizler sebebiyle oluşan mülteci akımlarını ele alıp krizin sınır aşan etkisini, yani uluslararası karakterini tespit ederek, bu iç krizin bölgede uluslararası barış ve güvenliği tehdit ettiğini tespit etme yoluna gitmektedir. Konsey kararlarında devletler arasında kuvvet kullanmanın yokluğunu ifade eden negatif barış anlayışından kopmamaya dikkat etmektedir.

Bunun birlikte Konsey BM Sözleşmesi'nin 39. maddesine dayanarak bir ülkenin iç işlerine karışma yasağını (BMS, md.2/7) ihlal edebilecek bir adım atmaktan çekinse de Konsey'in iç hukuka ait bazı şartların olmamasını, özellikle ağır insan hakları ihlalleri veya ağır insancıl hukuk ihlallerini zikretmesinden, bunları barış kavramı kapsamında üstü örtülü bir şekilde de olsa değerlendirdiği sonucu çıkartılabilir. Yani Konsey'in, uygulamalarında negatif barış anlayışını zorlayan geniş yorumlar yaptığı görülmektedir. ${ }^{136}$

Mali krizi Konsey'in bu yöndeki yorumlarına önemli bir örnek teşkil etmektedir. Mali Cumhuriyeti hakkında verilen kararlar incelendiğinde askeri darbe sonrası başlayan iç politik karışıklıklar ile yakından ilgilenilmiş olduğu görülmektedir. Özellikle yapısal konular, anayasal düzenin yeniden tesisi, ülkede 
kamu düzeninin yeniden tesisi için merkezi hükümetle işbirliği yapılması, güvenlik güçlerinin ve askerlerin geçici hükümetin işine karışmaması, bir an önce serbest seçimlerin yapılması, demokratik rejimin oluşturulması gibi konular sürekli olarak kararlarda taraflardan bağlayıcı olarak talep edilmiştir. Kararlarda ayrıca yine iç hukuku ilgilendiren birçok paragrafta insan hakları ihlallerinin ortadan kalkması, insancıl hukuk kurallarına riayet edilmesi direktifleri yer almıştır.

Konsey kararlarında, Kuzey Sahel bölgesinde ülkeler arasındaki sınırların kontrolündeki fiili zorluklar sebebiyle silahlı grupların, suç ve terör örgütlerinin bu ülkeler arasında rahatça her alanda faaliyet gösterebilmesinin Mali sınırları içindeki çatışmaları uluslararası bir krize dönüştürdüğü ifade edilmiştir. Bunun yanında komşu ülkelere olan göçler de nazara verilerek Mali Cumhuriyeti'ndeki durumun uluslararası barış ve güvenliği tehdit ettiği ifade edilmiştir. ${ }^{137}$ Şu halde, Konsey'in Mali krizine ilişkin kararlarında önemli ölçüde pozitif barış anlayışını dikkate almış olmakla birlikte, öteden beri bir krizin BM Sözleşmesi 39. maddeye göre uluslararası barış ve güvenliği tehdit ettiği tespitini yaparken krizin uluslararası yanını nazara vermesi uygulamasından vazgeçmediği görülmektedir.

Uluslararası terörizm uluslararası toplumun öteden beri özellikle 90'lı yıllardan bu yana üzerinde önemle durduğu bir konudur. Güvenlik Konseyi ilk defa, 11 Eylül 2001 saldırısı üzerine S/RES/1368 (2001) sayılı kararla terörü herhangi bir devlet bağlantısı olmaksızın ilk defa bir ülke bağlantısı olmaksızın soyut olarak 39. maddeye göre uluslararası barış ve güvenliğin tehdit eder olarak değerlendirmiştir. Bu karardan sonra Güvenlik Konseyi zaman zaman uluslararası terörizmi devletlerin katılımı olmasa dahi uluslararası barıșı tehdit eder olarak değerlendirmektedir. ${ }^{138}$

137 Konsey'in S/RES/2056 (2012) sayılı kararında kullandığ "the situation in Mali constitutes a threat to international peace and security in the region", "treat to internatinola peace and security in the region” olarak anlaşılmalıdır. Bölgesel barışın tehdit edilmesi Güvenlik Konseyi'nin görüşünde uluslararası barışın tehdit edilmesinin alt başlığıdır. Eğer ortada uluslararası veya bölgesel barışın tehdit edilmesi hâli varsa, burada sınır aşan silahlı çatışma tehdidinden bahsedilmektedir ki, burada klasik anlamda negatif barış kavramı söz konusudur.

138 Uluslararası terörizm BMGK tarafından ilk defa S/RES/635 (1989) ve 638 (1989) sayılı kararlarında herhangi bir uluslararası krizle bağlantılı olmaksızın soyut olarak ele alınmış ve bu kararlarda da herhangi bir barış tehdidi tespiti yapılmamıştır. Konsey Başkanının 31.01.1992 (S/23500 (1992) tarihli açıklamasında ise uluslararası terörizm BM Sözleşmesindeki ortak savunma sistemiyle sıkı bir bağlantı içinde olduğu dile getirilmiştir. S/RES/1269 (1999) sayılı kararda ise Konsey bir krizle bağlantılı olarak, devlet veya devlet dışı uluslararası terörizmin dünya barışı için bir tehlike oluşturduğunu ifade etmiştir. Ama teröre ilişkin herhangi bir krize çatışmaya dayanmayan en somut karar 11 Eylül 2001 saldırısı üzerine alınan S/RES/1368 (2001) sayılı karardır. Bu konud ayrıca bkz. Dicke, TLZ von s. 3; Bruha/Bortfled,s. 163. 
Konsey'in uluslararası terörizmi bir ülke bağlantısından uzak, soyut bir şekilde uluslararası barış ve güvenliği tehdit eder bir unsur olarak tespit eden kararı da düşünüldüğünde, bu karardan sonra artık uluslararası terör örgütlerinin faaliyet gösterdiği bölgelerde kriz sınır aşan unsuru olmasa bile Konsey BM Sözleşmesinin VII. bölümü çerçevesinde 39. maddeye dayanarak uluslararası barış ve güvenliği tehdit eden bir durum tespit edebilecektir.

Konsey Mali krizinde de hemen hemen bütün kararlarda uluslararası terörizm ve terör örgütlerinin, uluslararası barış ve güvenliği tehdit ettiğini ifade etmiştir. Belirtmek gerekir ki Konsey sadece Mali'deki terörist faaliyetlere dayanarak ülkedeki durumu uluslararası barış ve güvenliği tehdit eder olarak tespitte bulunabilirdi. Ancak Konsey böyle bir tercih yapmamıştır. Hem terör örgütlerinin faaliyetlerini, hem iç hukuka ilişkin konuları hem de mülteci akımları sebebiyle krizin uluslararası yönünü nazara vererek uluslararası barışın tehdit edildiğinin tespitini yapmıştır.

Güvenlik Konseyi’nin karar alırken bu alandaki gösterdiği hassasiyetlerden hareketle, onun yakın gelecekte BM Sözleşmesinde yer alan barış kavramını sadece pozitif barış anlamında ele alarak karar vermeyeceği tahmin edilebilir. 


\section{Kaynakça}

Bruha, Thomas - Bortfled, Matthias, Terrorismus und Selstverteidigung - Voraussetzungen und Umfang erlaubter Selstverteidigungsmassnahmen nach den Anschalegen von 11. September 2001, in Vereinte Nationen, 2001.

Dicke, Klaus, Einmütigkeit gegen die Taliban, in: Thüringische Landeszeitung vom 17.11.2001.

Schaefer, Andreas, Der Begriff der "Bedrohung des Friedens" in Artikel 39 der Charta der Vereinte Nationen: Die Praxis des Sicherheitsrates, Berlin, 2005.

\section{Internet:}

http://www.lag-malihilfe.de/mali-geschichte.htm

http://www.muz-online.de/afrika/mali.html

https://www.afrikanistik-aegyptologie-online.de/archiv/2015/4127 